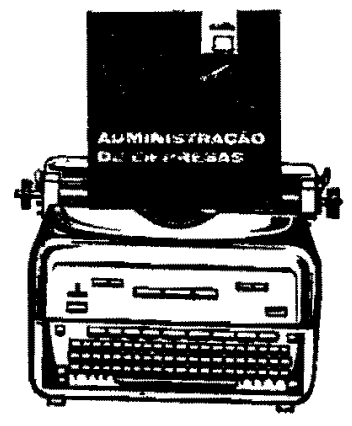

\title{
EDITORIAL \\ O "BOM SENSO" \\ EM ADMINISTRAÇÃO
}

Se há expressão atualmente em voga nas organizações brasileiras, em especial empresárias, essa é certamente "bom senso". Já a ouvimos para referir-se a caminho para solução de difíceis problemas de relações da administração com subordinados, a diretriz a seguir em decisão sôbre expansão das atividades da organização e a base de programa de racionalização de processos na emprêsa. Essas conotaçóes e muitas outras que ela pode adquirir lhe possibilitam tão livre trânsito e aceitação nas conversações, que não é raro observarmos que, basta que seja pronunciada em momentos cruciais de decisões administrativas, para que haja tranqüilização geral de ânimos ante a superioridade de raciocínio de quem tenha tido a feliz idéia de a pronunciar.

Que mágica palavra é essa e como foi que chegou a ter essa magia?

Ao nos socorrermos do dicionário para tentar conhecer as razões do fenômeno, nêle encontramos que "bom senso" se define como "aplicação perfeita da razão para julgar e raciocinar em cada caso particular da vida". Cremos ser êsse apenas um dos significados - e não o mais corrente - da expressão e, assim, mais uma vez, a dinâmica da linguagem avança em relação ao sentido estático e cristalizado das palavras, que é aquêle registrado no dicionário. 
Na prática temos ouvido, freqüentemente, o emprêgo de "bom senso" em outro sentido, que nos parece oposto a êsse: a consideração de fatos e fenômenos da realidade para fundamentar uma certa direção de raciocínio. Nesse sentido, seria sinônimo de "conhecimento baseado em experiência ou observação". Responde-se "vamos aplicar o bom senso para analisar o problema", na emprêsa, quando se pretende chamar a atenção para informações já conhecidas de problemas semelhantes que foram resolvidos de forma "convencional". O bom senso agiria, assim, como freio à aquisição de novos conhecimentos ou à observação da realidade de modo diverso do estabelecido em situações parecidas.

Já o significado que o dicionário dá a "bom senso" é descartiano, metódico: por êle se entende que é possivel chegar, de forma abstrata, ao conhecimento da realidade.

A predominância do primeiro sentido parece ser também comum em outros ramos da atividade humana. Uma das maiores casquinadas científicas dos tempos modernos foi a que saudou o teorema de MAXWELL segundo o qual a viscosidade dos gases aumenta com a temperatura. MAXWELL, pela teoria cinética dos gases, a êle chegou por raciocínio puro. A hilaridade só cessou quando experiências provaram que suas deduções estavam certas. A Física moderna não parece manter mais nenhuma relação com os sentidos, já que seus conceitos estão totalmente divorciados da observação direta da realidade; no entanto, diz STUART CHASE, continuamos a verificar que ainda predomina nela e em outros campos do conhecimento o bom senso, "aquilo que nos diz que a Terra é chata".

$\mathrm{Na}$ administração "científica" moderna a ênfase é dada aos métodos que incluem e analisam desde logo tôdas as alternativas possíveis de solução para cata problema ou conjunto de problemas. Êsses métodos exigem criatividade e imaginação, "males" que, segundo observamos, se combatem muitas vêzes na prática pelo "bom senso" no sentido mais corrente da expressão nas emprêsas. Daí talvez 
a magia da palavra: ela serve para "exorcismar" os "espíritos" que introduzem variáveis novas em situações que, com essas variáveis, se tornam incertas e inusitadas.

Por tudo isso se pode concluir que seria recomendável que o administrador considerasse cuidadosamente seu uso de "bom senso" para julgar situações e tomar decisões. Só assim se poderá saber se é preferível, em cada caso, o bom senso imaginativo, criativo e percuciente, ou o bom senso prudente, experiente e observador. Se isso não ocorrer haverá o perigo constante de estagnação - tranqüilizadora situação para muitos, mas decadência ou morte certa para organismos dinâmicos que dependem da inovação para não perecer.

Com êste número despeço-me dos leitores da RAE. Já a partir do n. $^{\circ} 22$ a responsabilituade pela Direção da Redação estará a cargo do Prof. CARLos Osmar Bertero, também do Departamento de Administração Geral e Relações Industriais da Escola de Administração de Emprêsas de São Paulo da Fundação Getúlio Vargas.

Torno públicos meus agradecimentos aos muitos - autores, leitores, Corpo Redatorial da RAE, professôres e funcionários da EAESP e da FGV e Gráfica Editôra Livro S. A. - que me incentivaram a realizar trabalho árduo, que se tornou especialmente compensador em virtude dêsse apoio.

Estcu certa de que o Prof. BerTero continuará a receber a mesma simpática e desvanecedora acolhida, estímulo por si só suficiente para que continue a ser realizada a tarefa ingente.

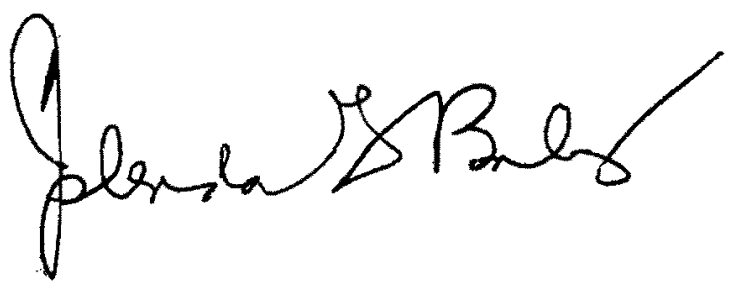

